\title{
SISTEM TES BERBASIS KOMPUTER UNTUK SELEKSI MITRA BADAN PUSAT STATISTIK
}

(Computer Based Test Systems for Contract Employees Recruitment in Indonesia National Statistics Office)

\author{
Adhi Candra Maulana ${ }^{1}$, Nori Wilantika² \\ Politeknik Statistika STIS ${ }^{1,2}$ \\ Jl. Otto Iskandardinata No.64C Bidaracina, Jatinegara, Jakarta Timur, 13330 \\ E-mail: 16.8964@stis.ac.id ${ }^{1}$, wilantika@stis.ac.id²
}

\begin{abstract}
ABSTRAK
Dengan misi menyediakan data statistik berkualitas, data yang disediakan oleh Badan Pusat Statistik harus mempunyai total survey error yang kecil. Total survey error mencakup sampling error dan nonsampling error, dengan nonsampling error yang berperan lebih besar. Dalam survei atau sensus yang dilaksanakan oleh BPS, nonsampling error ini sangat dipengaruhi oleh kualitas petugas lapangan yang direkrut oleh BPS dan biasa disebut dengan istilah "mitra statistik". Untuk mendapatkan calon mitra statistik yang berkualitas baik perlu melalui proses uji penilaian atau uji kelayakan menjadi seorang calon mitra. Proses uji penilaian saat ini masih menggunakan sistem ujian Paper and Pencil Test (PPT). Tes dengan metode PPT ini memiliki beberapa permasalahan diantaranya dari sisi keamanan soal dan transparansi nilai peserta. Penelitian ini bertujuan untuk mengembangkan sebuah sistem tes berbasis komputer untuk mengatasi permasalahan pada sistem ujian saat ini. Metode pengembangan sistem menggunakan metode modified waterfall. Hasil dari penelitian adalah sebuah sistem tes berbasis komputer bernama SICATMiS yang dikembangkan dari OSS TCExam. Sistem memiliki 3 aktor dan 5 menu utama yang dapat berjalan di luar jaringan (online) maupun di dalam jaringan local. Sistem yang dikembangkan dievaluasi dengan dengan uji scenario, uji penerimaan pengguna, dan system usability scale. Hasil uji skenario menunjukkan dari 47 skenario yang dilakukan, semua fitur berhasil dijalankan dengan sempurna. Dari 14 pernyataan dalam uji penerimaan pengguna, $68 \%$ responden sangat setuju bahwa SICATMiS telah memenuhi kebutuhan pengguna. Evaluasi SUS menunjukan SICATMiS dapat diterima dengan sangat baik dan siap digunakan.
\end{abstract}

Kata kunci-analisis dan perancangan sistem informasi, seleksi berbasis komputer, tbk, TCExam

\section{ABSTRACT}

With a mission to provide high quality statistical data, the data provided by the Statistics Indonesia (Central Bureau of Statistics) must have a small total survey error. The total survey error includes both sampling error and nonsampling error, with nonsampling error playing a bigger role. In surveys or censuses carried out by BPS, the non-ampling error is strongly influenced by the quality of field officers recruited by BPS or commonly referred as "mitra statistik". High quality "mitra statistik" are recruited through an assessment test. The current assessment test process is still using the Paper and Pencil Test (PPT) method. This method has several problems, especially the safety of the questions and the transparency of the participants'scores. This study aims to develop a computer-based test system to solve problems in the current exam system. The system development method is the modified waterfall method. The result of this research is a computerbased test system called SICATMiS which was developed from OSS TCExam. The system has 3 actors and 5 main menus that can run online or offline. SICATMiS was evaluated using scenario test, user acceptance test, and system usability scale. The scenario test results show that of the 47 scenarios performed, all features were executed perfectly. Of the 14 statements in the user acceptance test, 68\% of respondents strongly agree that SICATMiS has met user needs. The SUS evaluation also showed that SICATMiS was very well received and ready to use.

Keywords—system analysis and design, assesment test, cbt, cat, TCExam 


\section{PENDAHULUAN}

Badan Pusat Statistik (BPS) memiliki misi menyediakan data statistik berkualitas melalui kegiatan statistik yang terintegrasi dan berstandar nasional maupun internasional. Biemer (2010) menyatakan bahwa kualitas data yang baik secara umum harus memenuhi dimensi akurasi, yaitu mendapatkan data yang tepat sesuai dengan tujuan survei yang dilakukan dengan cara meminimalisir total survey error. Assael \& Keon (1982) menyatakan bahwa total survey errors disebabkan oleh sampling errors dan nonsampling errors. Nonsampling errors mempunyai peran yang lebih besar dalam menentukan kualitas sebuah survei. Nonsampling errors dapat disebabkan oleh kesalahan petugas, responden yang tidak bersedia disurvei, ketidaktepatan jawaban responden, dan berbagai hal lainnya. Petugas pencacah berperan besar dalam menentukan nonsampling errors ini. Dalam buku pedoman pengawas Survei Sosial Ekonomi Nasional (Susenas) yang dikeluarkan oleh BPS (2017), disebutkan bahwa petugas pencacah yang tidak berkualitas rentan melakukan moral hazard seperti tidak mentaati prosedur operasi standar (POS), mengganti responden, mengganti karakteristik responden dan tidak mendatangi responden (mencacah di atas meja).

Berdasarkan wawancara yang dilakukan kepada narasumber yang berasal dari BPS Republik Indonesia (RI) dan BPS Kabupaten Subang, dalam setiap sensus atau survei, BPS selalu melibatkan petugas nonpegawai organik sebagai petugas pencacah yang biasa disebut Mitra Statistik (Mitra). Mitra ini direkrut oleh BPS dari pegawai desa, pegawai kecamatan, kader Badan Pemberdayaan Masyarakat dan Keluarga Berencana (BPMKB), karang taruna, dan lainnya berdasarkan rekomendasi dari pemerintahan setempat (BPS RI, 2015). Para mitra ini harus mengikuti tes tertulis dan wawancara sebagai syarat menjadi petugas survei atau sensus (BPS RI, 2015).

Tes tertulis yang diikuti oleh calon mitra saat ini pada umumnya masih berbasis paper and pencil test (PPT). Masih berdasarkan wawancara kepada narasumber dari BPS RI dan BPS Kabupaten Subang, diketahui bahwa terdapat beberapa permasalahan pada kedua model tes tersebut khususnya dari sisi keamanan soal dan transparansi nilai peserta. Pertama, soal-soal untuk tes tertulis yang dilaksanakan oleh BPS selama ini belum dikelola dengan baik. Untuk setiap tes seleksi, BPS harus membuat soal baru. Penggunaan soal-soal yang lama juga menimbulkan kekhawatiran akan kebocoran soal. Kedua, dengan jumlah peserta yang banyak, BPS juga harus menyewa tempat pelaksanaan tes. BPS kemudian harus mencetak soal dan lembar jawaban yang cukup banyak serta harus mendistribusikannya ke tempat-tempat pelaksanaan tes. Hal ini juga membuka peluang kebocoran soal. Selain itu, di era pandemi saat ini, pelaksanaan tes dengan mengumpulkan banyak peserta di suatu tempat memiliki resiko penularan virus covid-19. Ketiga, dalam pelaksanaan tes, semua peserta mendapatkan jenis soal yang sama. Tidak ada variasi jenis soal maupun pengacakan urutan soal yang dikerjakan oleh peserta. Hal ini membuka peluang bagi peserta untuk mencontek dalam ujian. Keempat, berkaitan dengan peeriksaan hasil tes, seleksi model PPT ini membutuhkan banyak sumber daya manusia untuk mengoreksi hasil tes peserta secara satu persatu. Dalam proses pemeriksaan ini, petugas pengoreksi dapat membuat kesalahan atau bahkan memanipulasi nilai sehingga merugikan peserta. Test seleksi model PPT ini membutuhkan banyak tenaga untuk mengawasi tes dan memeriksa hasil tes. Dalam proses memeriksa jawaban hasil tes, petugas pemeriksa dapat membuat kesalahan memeriksa sehingga mengurangi nilai tes. Dengan kata lain, proses mulai dari koreksi hingga nilai diumumkan lama dan tidak transparan.

Berdasarkan permasalahan-permasalahan tersebut maka perlu dikembangkan sistem informasi yang dapat menggantikan sistem tes berbasis PPT. Computer-based test (CBT) telah digunakan sebagai pengganti PPT sejak lama, Bunderson dan Olsen (1988) mencatat istilah "computer 
assisted test" (CAT) muncul setelah disebutkan pada buku yang ditulis oleh Holtzman (1970). Ridgway et al. (2007) menjelaskan secara umum bahwa tes berbasis komputer atau Computer Based Test (CBT) atau Computer-based Assessment Test (CAT) adalah proses untuk merekam, mentransmisikan, mempersentasikan dan pengolahan bahan penilaian yang melibatkan penggunaan teknologi informasi dan komputer (TIK). CAT dapat diartikan juga tes atau penilaian yang dilakukan dengan komputer baik secara berdiri sendiri, terkonfigurasi dengan jaringan atau dengan perangkat lain yang terhubung dengan internet (Bunderson \& Olsen, 1988).

Penelitian terdahulu yang dilakukan oleh Poggio, Glasnapp, Yang, dan Poggio (2004), Noyes dan Garland (2008) dan Stephens (2001) menunjukan bahwa CAT dapat menggantikan PPT tanpa mempengaruhi hasil nilai peserta tes dengan proses penilaian yang lebih cepat. Biaya untuk mencetak soal dan kertas jawaban juga dapat dihilangkan sehingga dapat menekan biaya yang harus dikeluarkan. Anang et al. (2019) juga pernah mengembangkan CAT menggunakan open source sofware (OSS) TCExam dengan beberapa modifikasi agar sesuai dengan rancangan sistem yang telah ditentukan oleh peneliti. Hasil dari penelitian ini cukup berhasil dan telah digunakan sebagai pengganti tes berbasis PPT untuk pelaksanaan tes saringan penerimaan mahasiswa baru Politeknik Statistika STIS yang diadakan serentak di seluruh Indonesia.

Berdasarkan penelitian-penelitian tersebut, penelitian ini bertujuan untuk mengembangkan sistem berbasis komputer untuk seleksi mitra BPS. Sebelum mengembangkan sistem, peneliti melakukan kajian terhadap beberapa alternatif OSS untuk ujian berbasis komputer. Sistem dikembangkan untuk menyelesaikan permasalahan-permasalahan pada metode tes PPT yang yang telah disebutkan sebelumnya. Sistem juga dapat mendukung pelaksanaan tes jarak jauh untuk menghindari kerumunan dan mencegah penularan covid-19 antar peserta maupun dengan petugas.

\section{METODE}

Pengembangan sistem pada penelitian ini adalah mengikuti siklus modified waterfall. Satzinger, Jackson, dan Burd (2010) menjelaskan bahwa pada metode modified waterfall, setiap fase pada siklus hidup pengembangan sistem dapat berjalan secara bersamaan. Setiap komponen utama fase awal harus telah selesai terlebih dahulu, baru fase berikutnya dapat dimulai. Fase sebelumnya dapat tetap berjalan untuk melakukan penyesuaian mengikuti perkembangan yang terjadi dalam pengembangan sistem. Adapun tahapan pengembangan sistem dalam penelitian ini adalah sebagai berikut:

1. Persiapan. Pada tahapan ini dilakukan proses pengumpulan data/informasi menggunakan metode wawancara langsung dengan tiga orang narasumber yang berasal dari Politeknik Statistika STIS, BPS RI, dan BPS Kabupaten Subang. Wawancara bertujuan untuk mendapatkan informasi berupa proses bisnis dan permasalahan sistem seleksi mitra BPS yang sedang berjalan.

2. Analisis Kebutuhan Sistem. Berdasarkan hasil yang didapat pada proses sebelumnya, dilakukan identifikasi kebutuhan pengguna yang harus dipenuhi oleh sistem yang dikembangkan peneliti. Permasalahan-permasalahan pengguna diidentifikasi dari hasil wawancara pada tahapan sebelumnya dan dianalisis solusi yang mampu menyelesaikan permasalahan tersebut. Pada tahapan ini juga dilakukan kajian untuk menentukan kandidat OSS yang akan digunakan untuk pengembangan sistem.

3. Desain Sistem. Pada tahap ini dilakukan perancangan sistem usulan yang didasarkan dari solusi permasalahan yang didapat pada proses sebelumnya. Proses perancangan sistem usulan terdiri dari perancangan alur kerja sistem usulan yang digambarkan dalam diagram 
proses bisnis sistem usulan, pemilihan nama sistem usulan, perancangan proses sistem usulan menggunakan use case dan activity diagram, serta perancangan arsitektur sistem usulan.

4. Pengembangan Sistem. Pada tahap ini dilakukan pengimplementasian rancangan sistem usulan yang didapat dari proses sebelumnya. Pengimplementasian rancangan sistem usulan tersebut terdiri dari penyesuaian dan modifikasi fitur dan antarmuka OSS yang telah dipilih. Hasil yang didapat dari proses ini adalah sistem Tes Berbasis Komputer (TBK) untuk rekrutmen mitra BPS yang sesuai dengan rancangan sistem usulan.

5. Pengujian Sistem. Tahapan terakhir dari penelitian ini adalah pengujian terhadap sistem yang telah dibuat. Pengujian dilakukan dengan uji skenario, system usability scale (SUS), dan uji penerimaan pengguna (UAT). Melalui uji scenario, peneliti menguji apakah fungsi-fungsi yang ada dalam sistem sudah berjalan sesuai dengan yang diharapkan. Sedangkan melalui uji SUS akan diuji apakah sistem yang dibuat sudah bisa diterima oleh pengguna. Selanjutnya UAT dilakukan untuk menguji apakah sistem telah memenuhi kebutuhan pengguna saat ini. Uji SUS dan UAT dilakukan dengan memberika kuesioner kepada enam orang pegawai BPS Kabupaten Subang. Kuesioner SUS diadopsi dari Broke (1986) yang berisi 10 butir pertayaan. Sedangkan kuesioner UAT disusun sendiri oleh peneliti berisi 14 butir pertanyataan dengan model subjective continuum scale. Daftar skenario pada uji skenario dapat dilihat pada alamat http://tiny.cc/exojsz, kuesioner uji pemenuhan kebutuhan sistem dapat dilihat pada alamat http://tiny.cc/hxojsz, dan kuesioner uji SUS dapat dilihat pada alamat http://tiny.cc/jwojsz.

\section{HASIL DAN PEMBAHASAN}

\section{Analisis Kebutuhan Sistem}

Berdasarkan hasil wawancara yang dilakukan pada tahap persiapan, proses tes seleksi mitra BPS saat ini terbagi menjadi proses manajemen tes seleksi dan pelaksanaan tes seleksi. Proses manajemen dimulai dari menerima data calon mitra sebagai peserta tes, mengalokasikan para peserta tes dan pengawas tes ke dalam beberapa test center, membuat dan mencetak soal tes, mencetak lembar jawaban, menerima hasil tes, dan memasukan data hasil tes ke sistem rekrutmen mitra BPS. Proses pelaksanaan tes dimulai dengan membagikan soal dan lembar jawaban kepada peserta tes, mengawasi tes, memeriksa hasil tes, dan melaporkan hasil tes ke pihak manajemen.

Dari analisis yang peneliti lakukan, diperoleh usulan-usulan dan kebutuhan yang berkaitan dengan sistem TBK yang peneliti kembangkan. Sistem TBK yang dibutuhkan untuk proses tes seleksi mitra BPS harus memenuhi beberapa faktor, yaitu keamanan, akurasi, cepat dalam mendapatkan hasil tes sehingga dapat menggantikan sistem tes PPT saat ini. Untuk mengakomodir kebutuhan di era pandemi, sistem juga harus dapat digunakan dari jarak jauh.

Untuk memenuhi kebutuhan tersebut, maka sistem TBK yang dikembangkan pada penelitian ini memiliki fungsi-fungsi sebagai berikut:

1. Sistem dikembangkan dengan platform berbasis web.

2. Otorisasi. Setiap pengguna baik admin, pengawas maupun peserta harus login sesuai dengan basis data yang sudah ada, sehingga tidak ada pengguna yang tidak terdaftar yang dapat menggunakan aplikasi TBK ini.

3. Manajemen tes. Aplikasi TBK ini memiliki fitur manajemen tes seperti menambahkan pengguna, menghapus pengguna, mengubah data pengguna, ekspor data peserta dan hasil tes. Selain itu aplikasi ini juga memiliki fitur pengaturan tes dan pengawasan tes. 
4. Bank soal. Aplikasi TBK ini memiliki fitur memasukan soal baik secara manual maupun impor dan menyimpan soal tersebut kedalam bank soal sehingga dapat digunakan untuk keperluan tes lainnya. Aplikasi CAT ini juga mempunyai fitur pengacakan soal sehingga setiap peserta tes akan mendapatkan soal dan urutan jawaban yang berbeda dengan peserta lain.

5. Pemeriksaan hasil tes otomatis. Aplikasi CAT ini mempunyai fitur pemeriksaan hasil tes secara otomatis setelah peserta menekan tombol selesai tes atau saat waktu tes telah habis dan menyimpan hasilnya ke basis data. Peserta dapat mengetahui secara langsung hasil tesnya.

\section{Pemilihan Kandidat Sistem}

Kebutuhan-kebutuhan sistem yang telah dibahas sebelumnya dijadikan dasar dalam pemilihan kandidat OSS yang digunakan untuk mengembangkan sistem usulan. Terdapat tiga kandidat OSS yang dikaji, yaitu TCExam, PaperShala, dan FlexiQuiz.

Tabel 1. Analisis pemilihan software.

No. Kriteria

Lisensi
Platform
Modifikasi
Penyimpanan
Mode offline
Keamanan data
Terintegrasi dengan PPT
Dukungan bahasa Indonesia
Manajemen pengguna
Manajemen tes
Penjadwalan test
Fitur pengacakan soal dan bank soal
Laporan hasil tes otomatis
$\quad$ Total

Total

TCExam
100
100
100
100
100
100
100
100
100
100
100
100
100
$\mathbf{1 3 0 0}$

1300

$\begin{array}{cc}\text { Skor } & \\ \text { PaperShala } & \text { Flexiquiz } \\ 60 & 75 \\ 100 & 100 \\ 60 & 80 \\ 50 & 50 \\ 50 & 50 \\ 50 & 100 \\ 50 & 50 \\ 60 & 100 \\ 100 & 100 \\ 100 & 100 \\ 100 & 50 \\ 100 & 100 \\ 100 & 100 \\ \mathbf{9 8 0} & \mathbf{1 0 5 5}\end{array}$

Tabel 1 menunjukkan perbandingan ketiga kandidat OSS untuk dikembangkan menjadi sistem usulan. TCExam (www.tcexam.org) adalah sebuah open source system untuk tes secara elektronik (yang dikenal juga dengan CBA-Computer Based Assessment, CAT-Computer Based Test atau e-exam) yang membuat para pendidik dan pelatih untuk membuat, menjadwalkan, mengadakan dan melaporkan kuis dan tes (Tecnick.com, 2019). PaperShala (2020) adalah salah satu online examination system terbaik. PaperShala Online examination system mencakup hampir semua kebutuhan dasar ujian seperti pendaftaran siswa, verifikasi siswa, bank soal, penjadwalan ujian, kartu laporan instan, laporan siswa secara keseluruhan, dan lain-lain. PaperShala menyediakan tiga macam lisensi, yaitu gratis untuk jumlah siswa di bawah 100 orang, $\$ 5 /$ siswa/tahun untuk maksimum siswa 200 orang dan \$3/siswa/tahun untuk jumlah siswa maksimum 500 orang. FlexiQuiz adalah pembuat kuis dan penilaian online yang memungkinkan pengguna membuat tes khusus untuk karyawan, pelanggan, atau siswa. Penilaian dapat dipublikasikan secara pribadi untuk diakses hanya oleh kelompok-kelompok tertentu, atau secara publik untuk diambil oleh pendaftar mana pun, dan dinilai secara otomatis oleh perangkat lunak (nextSpark Pty Ltd., 2020). Berdasarkan Tabel 1, TCExam mendapatkan skor paling tinggi dibandingkan aplikasi sejenis, sehingga penulis memutuskan memakai TCExam sebagai dasar pengembangan sistem usulan. 


\section{Rancangan Sistem Usulan}

Sistem yang dikembangkan pada penelitian ini diberi nama SICATMiS. SICATMiS merupakan akronim dari Sistem Informasi Computer-based Assessment Test Mitra Statistik.

\section{Proses bisnis sistem usulan}

Dalam proses bisnis sistem usulan yang bisa dilihat pada Gambar 1, proses bisnis menjadi lebih pendek dan cepat. Tidak ada proses pencetakan dan distribusi soal serta lembar jawaban sehingga waktu dan biaya dapat dipangkas. Proses memeriksa lembar jawaban dan memasukkan data hasil ujian juga dapat dihilangkan, sehingga hasil dari tes peserta dapat segera didapatkan dan keputusan tentang calon peserta yang lulus dapat segera diambil tanpa terhambat proses lain.

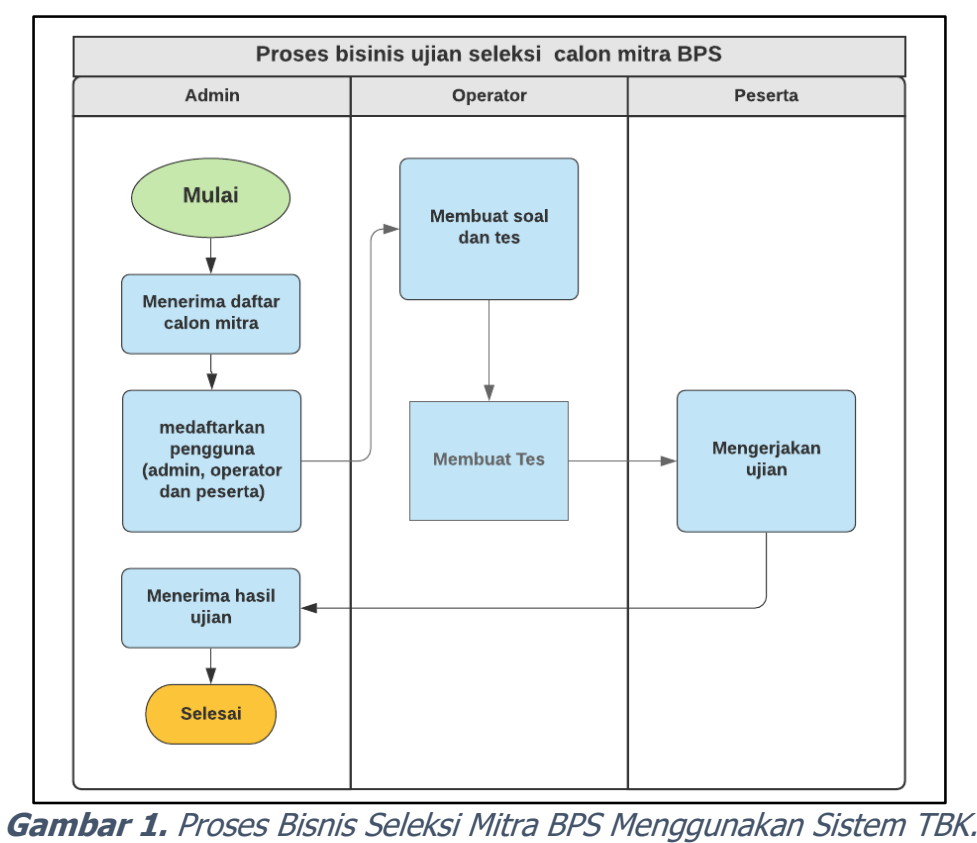

Berdasarkan kebutuhan sistem di atas, sistem SICATMIS memiliki beberapa use case yang dapat memenuhi kebutuhan sistem tersebut. Seperti yang ditunjukkan pada Gambar 2, Use case yang dimiliki adalah login pengguna, menambahkan pengguna, mengubah data pengguna, menghapus data pengguna, menambahkan soal, mengubah soal, membuat tes, mengikuti tes, dan menampilkan hasil tes. Sedangkan aktor utama dalam aplikasi SICATMIS ini adalah peserta, operator dan admin. 


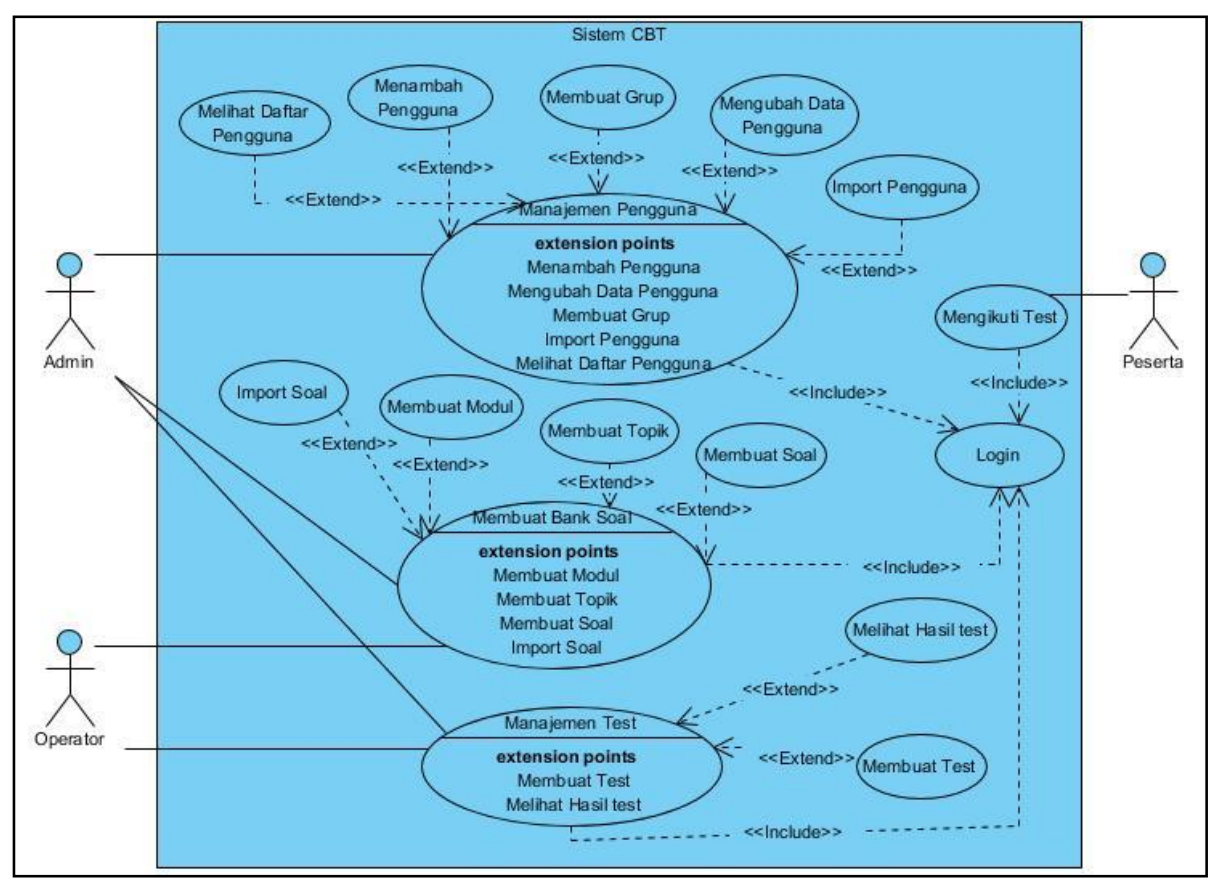

Gambar 2. Use Case SICATMiS.

\section{Arsitektur sistem usulan}

Sistem usulan ini dapat berjalan secara online maupun di dalam jaringan lokal atau offline architecture, karena tidak ada jaminan jaringan internet akan selalu ada saat tes berlangsung. Jaringan lokal ini juga dapat meningkatkan keamanan saat tes berlangsung dengan tidak adanya akses ke luar dan internet, sehingga hanya peserta yang dapat mengikuti tes. Dari Gambar 3 dapat dilihat bahwa pengguna dapat memakai PC, laptop, dan smartphone untuk dapat mengakses sistem. Pengguna menggunakan web browser dalam perangkatnya untuk mengakses sistem.

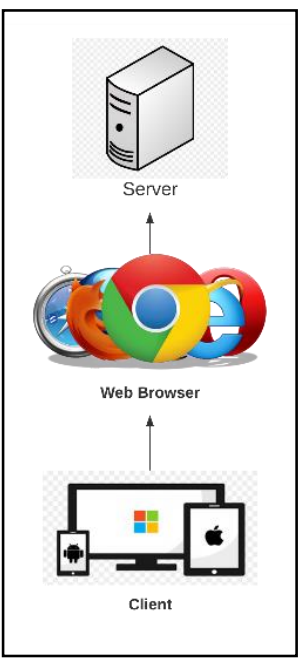

Gambar 3. Arsitektur sistem usulan.

\section{Pengembangan sistem}

Dalam sistem dan fasilitas yang telah disediakan oleh TCExam, terdapat beberapa hal yang perlu disesuaikan dengan rancangan sistem usulan. Hal ini juga perlu dilakukan untuk memudahkan pengguna dalam menggunakan SICATMiS. Dari beberapa perubahan dan penyesuaian yang dilakukan oleh peneliti, di antaranya dapat dilihat pada Tabel2. 
Tabel 2. Daftar pengembangan SICATMiS.

No. Perubahan

1 Menghilangkan fungsi daftar mandiri user baru

2 Menghilangkan opsi pada menubar

3 Menghilangkan opsi-opsi dalam form user

4 Menghilangkan beberapa opsi pilihan dalam form soal

5 Menghilangkan beberapa opsi pilihan dalam form jawaban.

6 Menyediakan contoh file untuk mengimpor soal dan pengguna dan menyediakan link untuk mengunduhnya.

\section{Keterangan}

Menghilangkan fungsi user untuk mendaftarkan diri sendiri.

Menghilangkan beberapa opsi pada menu sesuai dengan privilege dan keperluan BPS.

Menghilangkan opsi-opsi yang tidak diperlukan dalam form pengisian data user sehingga menjadi lebih sederhana dan mudah digunakan.

Menghilangkan opsi-opsi yang tidak diperlukan dalam form soal.

Menghilangkan opsi-opsi yang tidak diperlukan dalam form jawaban. TCExam tidak menyediakan contoh file untuk diunggah.

Beberapa hasil implementasi antarmuka SICATMiS dapat dilihat pada Gambar 4 hingga

\section{Gambar 6.}

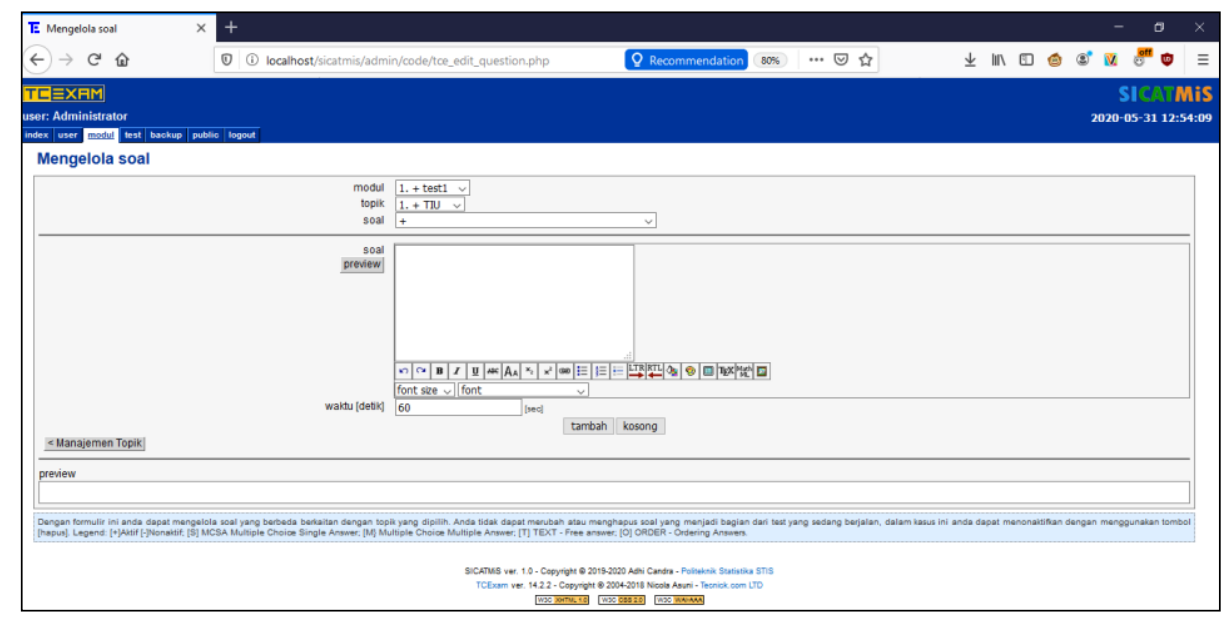

Gambar 4. Implementasi tampilan antarmuka halaman tambah soal 


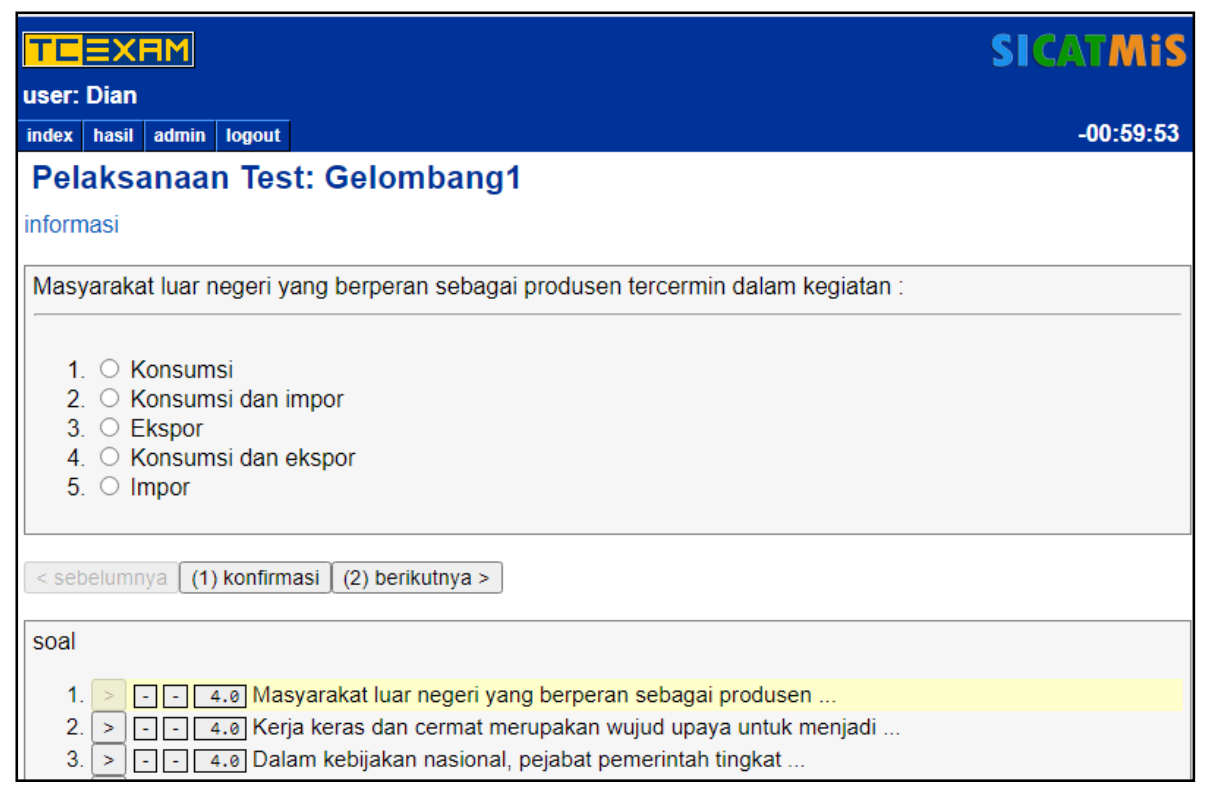

Gambar 5. Implementasi tampilan antarmuka halaman mengerjakan tes

\begin{tabular}{|c|c|c|c|c|}
\hline \multicolumn{5}{|c|}{$\begin{array}{l}\text { TᄃEXFM } \\
\text { user: Dian }\end{array}$} \\
\hline \multicolumn{5}{|c|}{ 2020-06-07 13:02:39 } \\
\hline \multicolumn{5}{|l|}{ Test List } \\
\hline test & dari & ke & status & action \\
\hline Gelombang1 & $2020-06-0422: 40: 08$ & $2020-06-07$ 22:40:00 & $11.000 / 140.000(8 \%)-$ GAGAL & \\
\hline Ini adalah halams & in utama dari TCExam. D & ari halaman ini anda dapat & memulai atau melanjutkan test & \\
\hline \multicolumn{5}{|c|}{$\begin{array}{l}\text { SICATMiS ver. } 1.0 \text { - Copyright } \Theta 2019-2020 \text { Adhi Candra - Politeknik Statistika STIS } \\
\text { TCExam ver. } 14.22 \text { - Copyright @2004-2018 Nioola Asuni - Tecrick com LTD }\end{array}$} \\
\hline
\end{tabular}

Gambar 6. Implementasi tampilan antarmuka halaman hasil tes

\section{Uji coba sistem}

Uji coba dilakukan di BPS Kabupaten Subang dengan responden berjumlah enam orang, yaitu empat orang Kepala Seksi, satu orang KSK, dan satu orang mitra. Uji coba dilaksanakan pada tanggal 5 Juni 2020, dengan dua orang berperan sebagai admin, dua orang berperan sebagai operator, dan dua orang berperan sebagai calon mitra. Para responden diberikan panduan pemakaian SICATMiS untuk dipelajari dan mencoba dengan peran masing-masing sesuai dengan skenario yang telah disiapkan oleh penulis. Selanjutnya masing-masing diberikan kuesioner uji pemenuhan kebutuhan sistem dan kuesioner uji SUS.

\section{Uji Skenario}

Hasil dari pengujian sistem dengan cara uji skenario testing dapat dilihat pada https://laci.bps.go.id/s/6F0wzUVjF9ITMCX. Uji skenario sebanyak 47 skenario semua berjalan dengan sempurna. Dengan hasil uji skenario ini maka SICATMiS dapat digunakan dengan sebagaimana mestinya. 


\section{Uji Penerimaan Pengguna (UAT)}

Uji pemenuhan kebutuhan sistem ini dilakukan untuk melihat apakah sistem yang dikembangkan oleh penulis dapat memenuhi kebutuhan sistem baik fungsional maupun non-fungsional. Hasil dari uji penerimaan pengguna dapat dilihat secara detil di http://tiny.cc//xojsz. Hasil uji tersebut menunjukan bahwa $68 \%$ responden menyatakan sangat setuju bahwa SICATMiS dapat memenuhi kebutuhan pengguna dalam rekrutmen mitra BPS, 18\% menyatakan setuju, dan 14\% menyatakan netral.

\section{Uji SUS}

Berdasarkan hasil uji SUS pada Tabel 3 dapat dilihat bahwa SICATMiS mendapatkan skor akhir sebesar 80,417. Skor ini menunjukan bahwa SICATMiS mendapatkan nilai A atau sangat baik, sehingga menunjukan bahwa SICATMiS dapat diterima dan digunakan oleh pengguna. Namun ada poin pernyataan yang perlu menjadi perhatian yaitu poin 10 "Saya perlu membiasakan diri terlebih dahulu sebelum menggunakan sistem ini." yang rendah pada hampir semua responden, hal ini menunjukan bahwa pengguna harus membiasakan diri dahulu sebelum dapat menggunakan SICATMiS dengan baik.

Tabel 3. Skor hasil uji SUS

No

\begin{tabular}{rrrrrrrr}
\multicolumn{2}{r}{ Skor } & & & & & Jumlah & \multicolumn{1}{c}{$\begin{array}{c}\text { Skor } \\
\text { akhir }\end{array}$} \\
5 & 6 & 7 & 8 & 9 & 10 & & 62,5 \\
4 & 2 & 3 & 2 & 4 & 0 & 25 & 80 \\
4 & 4 & 3 & 4 & 4 & 1 & 32 & 60 \\
3 & 2 & 2 & 2 & 3 & 1 & 24 & 92,5 \\
4 & 4 & 4 & 4 & 4 & 1 & 37 & 90 \\
4 & 4 & 4 & 3 & 4 & 3 & 36 & 97,5 \\
4 & 4 & 4 & 4 & 4 & 3 & 39 & 80,417
\end{tabular}

Untuk mempermudah pengguna dalam menggunakan SICATMiS, penulis membuat panduan penggunaan SICATMiS yang dapat diunduh di alamat http://tiny.cc/7wojsz. Panduan penggunaan SICATMiS ini merupakan cara-cara menggunakan SICATMiS mulai dari instalasi di server, manajemen pengguna, manajemen bank soal, manajemen test hingga pengerjaan tes. Sedangkan untuk pengembangan sistem selanjutnya dapat dengan mudah dilakukan karena dokumentasi program yang cukup lengkap pada setiap file.

\section{KESIMPULAN}

Berdasarkan hasil penelitian yang telah dilakukan, dapat ditarik kesimpulan sebagai berikut, Alternatif solusi yang penulis kaji untuk sistem tes berbasis komputer untuk seleksi mitra BPS adalah TCExam. TCExam mempunyai fitur-fitur dan karakteristik yang mampu memenuhi kebutuhan sistem yaitu keamanan tes terjamin dari kebocoran dan kecurangan, cepat dalam mendapatkan nilai tes, transparan dalam hasil tes, serta ringan dan dapat diakses melalui berbagai media (PC, Laptop, gawai). Pengembangan sistem dilakukan dengan melakukan beberapa penyesuaian agar sesuai dengan kebutuhan sistem dan memudahkan dalam pemakaian. Hasil uji skenario menunjukkan dari 47 skenario yang dilakukan, semua fitur berhasil dijalankan dengan sempurna. Dari 14 pernyataan dalam uji penerimaan pengguna, 68\% responden menyatakan sangat setuju, $18 \%$ responden menyatakan setuju dan $14 \%$ menyatakan netral dengan pernyataan bahwa SICATMiS telah memenuhi kebutuhan pengguna. Evaluasi memakai SUS mendapat skor akhir akhir sebesar 80,417. Skor ini menunjukkan bahwa SICATMiS mendapatkan 
nilai A atau sangat baik, sehingga menunjukkan bahwa SICATMiS dapat diterima dengan sangat baik dan siap digunakan. Namun, pengguna harus membiasakan diri dahulu sebelum dapat menggunakan SICATMiS dengan baik.

Dalam penelitian ini tentunya masih banyak kekurangan dan masih perlu adanya penelitian lebih lanjut. Perbaikan tampilan, pemilihan warna, tata letak informasi, penambahan highlight, serta perlu diteliti bagaimana cara supaya aplikasi tidak kaku dan membosankan. Perlu perbaikan dalam algoritma pengacakan soal, karena terdapat jeda yang mengganggu saat memulai tes, terutama saat pengguna secara serentak menekan tombol mulai tes. Perlu diteliti lebih lanjut tentang manajemen tes dan prosedur operasi standar tes seleksi, sehingga tes seleksi dapat benar-benar dapat dilaksanakan dengan aman kecurangan. Perlu diteliti secara lebih lanjut terkait dengan set soal yang akan diujikan, sehingga benar-benar dapat menyaring calon mitra yang berkualitas.

\section{DAFTAR PUSTAKA}

Anang, Y., Takdir, Ridho, F., Santoso, I., Maghfiroh, L. R., Mariyah, S., ... Watanabe, Y. (2019). Implementation of Computer-Based Test in a Countrywide New Student Recruitment Process. 2019 4th International Conference on Information Technology (InCIT), 268-273. https://doi.org/10.1109/INCIT.2019.8912026

Assael, H., \& Keon, J. (1982). Nonsampling vs. Sampling Errors in Survey Research. Journal of Marketing, 46(2), 114. https://doi.org/10.2307/3203346

Biemer, P. P. (2010). Total survey error: Design, implementation, and evaluation. Public Opinion Quarterly, 74(5), 817-848. https://doi.org/10.1093/poq/nfq058

BPS (Badan Pusat Statistik). (2017). PEDOMAN PENGAWAS SUSENAS MARET 2017(Sub Direktorat Statistik Rumah Tangga, Ed.). Jakarta: Badan Pusat Statistik, Jakarta - Indonesia.

BPS (Badan Pusat Statistik). (2019). Badan Pusat Statistik. Diambil 29 November 2019, dari https://www.bps.go.id/menu/1/informasi-umum.html

BPS (Badan Pusat Statistik). (2015). Buku Pedoman Teknis BPS Provinsi dan BPS Kabupaten/Kota Listing SE2016. BPS RI.

Brooke, J. (1986). System usability scale (SUS): a quick-and-dirty method of system evaluation user information. Reading, UK: Digital equipment co Itd, 42, 1-7.

Bunderson, C. V., \& Olsen, J. B. (1988). THE FOUR GENERATIONS OF COMPUTERIZED EDUCATIONAL MEASUREMENT. ETS Research Report Series, 1988(June 1988), i-148.

nextSpark Pty Ltd. (2020). Flexiquiz. Diambil 26 Juni 2020, dari https://www.flexiquiz.com/

Noyes, J. M., \& Garland, K. J. (2008). Computer- vs. paper-based tasks: Are they equivalent? Ergonomics, 51(9), 1352-1375. https://doi.org/10.1080/00140130802170387

PaperShala.com. (2020). PaperShala. Diambil 1 Juli 2020, dari https://papershala.com/

Poggio, J., Glasnapp, D. R., Yang, X., \& Poggio, A. J. (2004). A comparative evaluation of score results from computerized and paper \& pencil mathematics testing in a large scale state assessment program. Journal of Technology, Learning, and Assessment, 3(6).

Ridgway, J., Mccusker, S., Pead, D., Ridgway, J., Mccusker, S., Pead, D., ... Nesta, E. A. (2007). Literature Review of E-assessment. hal-00190440, 44(February), 1-52.

Satzinger, J. W., Jackson, R. B., \& Burd, S. D. (2010). Systems Analysis and Design in a Changing World Fifth Edition (5th ed.). Cengage Learning.

Stephens, D. (2001). Use of computer assisted assessment: Benefits to students and staff. Education for Information, 19(4), 265-275. https://doi.org/10.3233/EFI-2001-19401

Tecnick.com. (2019). TCExam. Diambil 28 Desember 2019, dari https://tcexam.org/ 